\title{
No-till and direct seeding agriculture in irrigated bean: Effect of incorporating crop residues on soil water availability and retention, and yield
}

\author{
João V.R.S. Souza ${ }^{\mathrm{a}, *, 1}$, João C.C. Saad ${ }^{\mathrm{a}, 1}$, Rodrigo M. Sánchez-Románn ${ }^{\mathrm{a}, 1}$, \\ Leonor Rodríguez-Sinobas ${ }^{\mathrm{b}, 2}$ \\ a Universidade Estadual Paulista Júlio de Mesquita Filho, Faculdade de Ciências Agronômicas de Botucatu, Brazil \\ ${ }^{\mathrm{b}}$ Research Group “Hydraulics for Irrigation” of the Technical University of Madrid, Spain
}

\section{A R T I C L E I N F O}

\section{Article history:}

Received 15 September 2015

Received in revised form

23 December 2015

Accepted 7 January 2016

Available online 21 January 2016

\section{Keywords:}

TDR

Crop residues

Common bean

Soil moisture

Water retention

Yield

\begin{abstract}
A B S T R A C T
Brazil is one of the top world producers of the staple commodity common bean (Phaseolus vulgaris L.). Irregular distribution of rainfall and the lack of rain during the crop reproductive phases affect its yield and increase the demand of water for irrigation. However, in recent years, water resources have decreased and water saving has become an issue. Thus, soil management techniques, which reduce evaporation, and efficient irrigation programming, through the monitoring of soil water content, could be adopted in water scarcity scenarios. This study assesses the effect of crop residues management (incorporated IR or left on soil surface NR) in soil water availability (and its retention in the soil pore space), and yield in common beans cultivated under no-till and directly seeded in an irrigated farm located southwest of São Paulo state. Soil water content was monitored with TDR probes installed within the $0-20 \mathrm{~cm}$ layer and its retention was assessed through the soil water retention curve. For the same irrigation management, the IR led to soil water content was lower than NR but both soil managements had similar available water and their demand of water for irrigation was similar. For the same soil water content, NR soils could hold it tightly in the pore space and the root plant system would require higher energy to absorb it. Then, it is foreseen that the root system in IR soils will be shallower than in NR soils, since it will withdraw water easily within the first $20 \mathrm{~cm}$, however, in NR, the roots will extend deeper searching for available water. Considering $40 \mathrm{kPa}$ as a threshold value, the plants suffered water stress during all crop cycle at the same physiologic stages in both soils. The variables studied to assess yield presented no-statistical significance in the $T$ test at significance level of 0.05 .
\end{abstract}

(C) 2016 Elsevier B.V. All rights reserved.

\section{Introduction}

The benefits of conservation agriculture, comprising no-till as well as reduced tillage practices (subsoiling, deep ploughing), have long been recognized, and they are accentuated in combination

\footnotetext{
* Corresponding author at: Universidade Estadual Paulista Júlio de Mesquita Filho, Faculdade de Ciências Agronômicas de Botucatu, Rua José Barbosa de Barros, no. 1780, Fazenda Lageado, Caixa-postal: 237, 18603970 Botucatu, SP, Brasil.

E-mail addresses: joao.vrs@outlook.com (J.V.R.S. Souza), joaosaad@fca.unesp.br (J.C.C. Saad),rmsroman@fca.unesp.br (R.M. Sánchez-Román)

leonor.rodriguez.sinobas@upm.es (L. Rodríguez-Sinobas).

1 Universidade Estadual Paulista Júlio de Mesquita Filho, Faculdade de Ciências Agronômicas de Botucatu. Rua José Barbosa de Barros, no. 1780, Fazenda Lageado, Caixa-postal: 237, 18603970 Botucatu, SP, Brasil.

2 Research Group "Hydraulics for Irrigation”, Technical University of Madrid Agricultural Engineering School, Ciudad Universitaria, 28040 Madrid, Spain.
}

with crop residues application. Crop residues on the soil surface protect the soil and reduce its erosion (Boulal et al., 2011; Brouder and Gomez-Macpherson, 2014) and runoff (Buschiazzo et al., 1998; Thomas et al., 2007). They also enhanced fertility and soil quality mainly by increasing soil organic matter (Bhattacharyya et al., 2012, 2013; Jemai et al., 2013; Ladha et al., 2009; Verhulst et al., 2010), which, in turn, may increase soil carbon sequestration (Palm et al., 2014).

Conservative agriculture systems also improve aggregate stability (Blanco-Canqui and Lal, 2007; Keller et al., 2007) and total porosity (Jemai et al., 2013; Lipiec et al., 2006; Mulumba and Lal, 2008) and as a consequence, soil moisture content increases (Govaerts et al., 2007; Gruber et al., 2011; Sharma et al., 2011) as well as water content availability (Bescansa et al., 2006; Jemai et al., 2013). In addition, infiltration (Bhattacharyya et al., 2006; 
Nielsen et al., 2009), water retention (Datiri and Lowery, 1991) and hydraulic conductivity (Benjamin, 1993) are improved as well.

In Brazil, a surface of about $25,000,000$ ha was cultivated under non tillage practices in 2007. Farmers have adopted this technology not only due to environmental issues (erosion control, improvement of soil fertility), but mainly due to its economical aspects (less labor work, higher profits) (Casão Junior et al., 2012). Sorrenson and Montoya (1984) highlighted that non tillage was the most cost effective means of controlling erosion in Brazil.

Common bean (Phaseolus vulgaris L.) is the most important eating legume worldwide and is a staple commodity in developing countries (Broughton et al., 2003). Brazil is the largest producer with $17.3 \%$ of the world production, followed by India $(16.4 \%)$, Myanmar (9.6\%), China (6.7\%), United States (6.3\%) and Mexico with $5.4 \%$ (FAO, 2009).

Approximately, $60 \%$ of the world's common beans cultivated areas are concentrated in regions that suffer water scarcity, where the crop is under water stress, the second major cause of yield loss (Singh, 1995). Drought can modify leaf development and thus, affect grain yield by reducing the active leaf area for photosynthesis (Guimarães, 1996; Fancelli and Dourado Neto, 1991). Plant height, leaf area index, number of seeds per pod, number of pods per plant and yield are reduced in plants suffering from water stress (Monteiro et al., 2010), although the number of pods per plant was the most sensitive variable to maintain a potential yield (Guimarães et al., 2011; Miorini et al., 2011). Likewise, the bean root system develops mostly in the upper soil layer enhancing the sensitivity of the crop to water stress and reinforcing the role of irrigation water supply for proper crop development during scarce rainfall periods (Carlesso et al., 2007). The response of common bean species to different water regimes in controlled environment showed that water consumption in plants with highest irrigation frequency was smaller than those less frequently irrigated, which suggested that they suffered some stress (Bourgault and Smith, 2010). Likewise, the efficiency of crop water used for leaf area development was different in the two species studied (common beans and mud beans). In addition, under low soil moisture conditions, plants developed a conservative water use by lowering maximum transpiration rates.

Common beans in Brazil are cultivated nationwide in different sowing dates and under different climatic conditions alternating water surplus and deficit periods. Since crop is sensitive to water stress, irrigation is needed in regions where rainfall is unevenly distributed to maintain yield and farmersí benefits (Didonet, 2005; Guimarães et al., 2011). Farmerís revenue in irrigation areas is about $70 \%$ higher than in rain fed crops (Silveira et al., 2001) although under stress conditions, a $20 \%$ yield decrease has been reported by Miorini et al. (2011)

In Brazil, irrigation demands about $72 \%$ of the water (Alves, 2015) and water resources are increasingly scarce every year. Considering this scenario, we can expect that water resources will be less available for irrigated agriculture and competition for water will increase in the near future. Within this context, conservative agriculture (no-till, direct seeding) along with a proper soil water content monitoring could be key factors for saving water by reducing evaporation and improving irrigation programming. In this regard, studies on conservative agriculture in common bean, mainly in Brazil, are numerous, but none has compared the effect of crop residue management on water availability and retention in the soil pore network during the crop cycle.

The objective of this study was to evaluate the effect of crop residues management (incorporated and non-incorporated into the soil) on soil water availability (and its retention in the soil pore space), during all the phenology stages, and yield in common beans cultivated under non tillage conditions and directly seeded irrigated agriculture.

\section{Materials and methods}

\subsection{Experimental site}

The field experiments were conducted at "Olhos D'água" farm (latitude: $23^{\circ} 33^{\prime} 21.14^{\prime \prime}$; longitude: $48^{\circ} 52^{\prime} 43.86^{\prime \prime} \mathrm{W}$ ) in the southwestern region of the State of São Paulo (Brazil). The farm is a member of the No-till and Planting in the Straw Irrigators Association of South western São Paulo, ASPIPP.

The farmer follows no-till and direct seeding farming, leaving the crop residue from the previous harvest over the soil, since 2007. In this year, he ploughed the soil and made deep harrows adding calcium carbonate $\left(\mathrm{Ca}_{2} \mathrm{CO}_{3}\right)$ to maintain soil $\mathrm{pH}$ at 5.5 . These tasks are performed once every ten years. Maize, common beans, soybeans and wheat are the main cultivated crops.

For this study, an irrigated area of 20 ha was selected with a crop rotation of maize-common beans.

\subsection{Water application by the irrigation system}

The area is irrigated in sectors of $180^{\circ}$ by a $361.75 \mathrm{~m}$ long center pivot (Lindsay, Zimmatic model) which is hold by seven towers. The system operates with an inlet pressure head of $50.05 \mathrm{~m}$ and a discharge of $260 \mathrm{~m}^{3} \mathrm{~h}^{-1}$. Considering these conditions, a field evaluation of the irrigation system was performed following the ABNT-NBR 14244 (ABNT, 1998). The uniformity of water application was calculated by the Christiansen Uniformity Coefficient-CUC as:

$\mathrm{CUC}=\left(1-\frac{\sum_{i=1}^{N}\left|H_{i}-H_{m}\right|}{N \times H_{m}}\right) \times 100$

where $H_{i}$ is the height of water collected in the collector (mm), $H_{\mathrm{m}}$ is the average water height from all the collectors $(\mathrm{mm})$, and $N$ is the number of collectors.

The irrigation events (water depth and time) are programmed by the farmer to supply the crop water requirements estimated with the data monitored in the farm's weather station. However, a limit of $16 \mathrm{~mm}$ water depth per irrigation is imposed, considering the pumping system specifications, the number of center pivots with simultaneous irrigation and the cost of energy, which varies along the day.

\subsection{Field preparation}

This study evaluated the performance of two different soil management practices: crop residues left on the soil (non-incorporated residues NR) and incorporated in the soil (IR). Thus, two parallel $6 \mathrm{~m}$ width soil strips were selected along the center pivot radius. Each strip followed a randomly alternation of areas with maize residues left on the soil (NR) and incorporated in the soil (IR) as it is described in Fig. 1. Thus, the pattern of alternating NR and IR areas in both strips was opposite. The length for each area was the spacing between the center pivot towers $(50 \mathrm{~m})$ which was considered adequate for a uniform crop residues' incorporation.

A 28-inch disc harrow was used for the incorporation of maize residues at $17 \mathrm{~cm}$ depth, 22 days before planting. Five successive passes of the disc harrow were necessary to fully incorporate the residues in the selected areas. Then, a leveled harrow disaggregated soil clods and leveled up the soil surface.

\subsection{Soil characteristics}

Soil texture was determined in three soil samples collected along the center pivot radius at two layers of $0-20 \mathrm{~cm}$ and $20-40 \mathrm{~cm}$. The samples from both layers were analyzed, however, 
Table 1

Results of soil analysis.

\begin{tabular}{|c|c|c|c|c|c|c|c|c|c|c|c|c|}
\hline $\begin{array}{l}\text { Layer } \\
(\mathrm{cm})\end{array}$ & $\begin{array}{l}\mathrm{pH} \\
\mathrm{CaCl}_{2}\end{array}$ & $\begin{array}{l}\text { O.M. } \\
\left(\mathrm{g} \mathrm{dm}^{-3}\right)\end{array}$ & $\begin{array}{l}P_{\text {resin }} \\
\left(\mathrm{mg} \mathrm{dm}^{-3}\right)\end{array}$ & $\begin{array}{l}\mathrm{H}+\mathrm{Al} \\
\left(\mathrm{mmol}_{\mathrm{c}} \mathrm{dm}^{-3}\right)\end{array}$ & & $\mathrm{Ca}$ & $\mathrm{Mg}$ & CEC & V\% & $\begin{array}{l}\text { Sand } \\
\left(\mathrm{g} \mathrm{kg}^{-1}\right)\end{array}$ & $\begin{array}{l}\text { Clay } \\
\left(\mathrm{g} \mathrm{kg}^{-1}\right)\end{array}$ & $\begin{array}{l}\text { Silt } \\
\left(\mathrm{g} \mathrm{kg}^{-1}\right)\end{array}$ \\
\hline $0-20$ & 5.3 & 40 & 77 & 35 & 4.4 & 59 & 15 & 113 & 69 & 89 & 652 & 259 \\
\hline
\end{tabular}

Note: $\mathrm{O} . \mathrm{M}=$ organic matter; $\mathrm{P}_{\text {resin }}=$ phosphorus in resin; $\mathrm{CEC}=$ cation exchange capacity, $\mathrm{V} \%$ = base saturation.
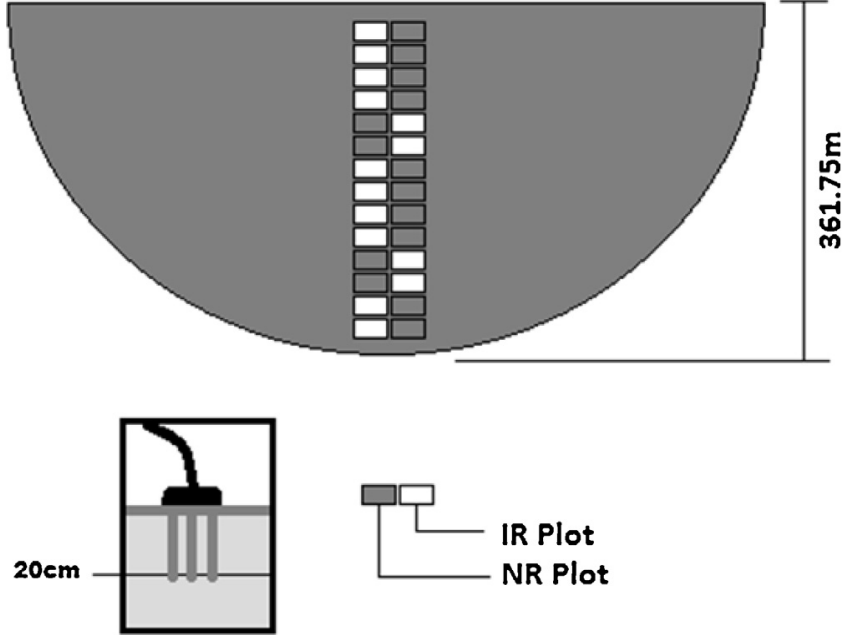

Fig. 1. Sketch with the distribution of NR and IR areas along the pivot center radius and placing of the TDR probe.

since they had the same texture "clay", an average value for the mineral components is depicted in Table 1 . Other 20 soil samples, randomly selected along the center pivot radius at the $0-20 \mathrm{~cm}$ layer, were thoroughly mixed to analyze chemical properties by the procedure proposed by Raij et al. (2001) at the Soil Fertility Laboratory of FCA/UNESP, Botucatu. The results for soil analysis are shown in Table 1.

Two soil water retention curves were determined: one for the IR soil management in disturbed soil samples, and the other for the NR in non-disturbed soil samples. All samples were collected 11 days prior to the land preparation labors for incorporating the maize residue. First, the maize residue was removed from the soil and then, 20 undisturbed soil samples were extracted with a $50 \mathrm{~mm}$ diameter and $50 \mathrm{~mm}$ height cylinder along the pivot center radius at depths from 8 to $13 \mathrm{~cm}$ as it is shown in Fig. 2. In addition, another 20 soil samples were collected with a shovel at the same time and location but the soil was graded through a $2-\mathrm{mm}$ sieve, and then mixed thoroughly. Then, these samples were sent to the soil physics laboratory of the FCA/UNESP, Botucatu, to determine the soil water retention curve by the methodology proposed by Claessen et al. (1997). The software Soil Water Retention Curve SWRC (DouradoNeto et al., 2000) was used to fit the experimental data.

Finally, soil bulk density and porosity were determined from the non-disturbed soil samples following the procedure (Claessen et al., 1997), yielding $1.19 \mathrm{~g} \mathrm{~cm}^{-3}$ and 55\%, respectively.

\subsection{Crop management and water requirements}

The maize crop was harvested between July 8th and July 10th, 2014 and then in August 22th 2014, the common bean was sown by applying 10 seeds per meter in rows spaced by $0.45 \mathrm{~m}$. Germination took place five days after sowing and the final stand was eight plants per meter. The whole cycle of the common bean lasted 90 days.

The crop water requirements ETa for the different stages were estimated as

$\mathrm{ETa}=\mathrm{kcETo}$ where ETo is the reference evapotranspiration and kc the crop coefficient corresponding to each phenology stage.

The FAO Penman-Monteith equation is usually recommended to calculate ETo (Allen et al., 2006) but the Hargreaves and Samani (1985) equation was used for its calculation since the first equation required several climatological variables that were not available at the climatic station located in the field site. The Hargreaves and Samani equation gives accurate estimations in arid environment (Raziei and Pereira, 2013) and only requires two variables:

ETo $=0.0135\left(T_{\text {med }}+17.78\right)$ Rs

where $T_{\text {med }}$ is the average temperature and Rs is the solar radiation. The first was calculated with the temperatures logged in the climatic station at the experimental site, and the second corresponded to the values logged in another experimental station $20 \mathrm{~km}$ from the first.

The $\mathrm{k}_{\mathrm{c}}$ selected for the different crop stages were those proposed by Alfonsi et al. (1990) for common beans that were grown in the north of the State of São Paulo.

In addition, a daily soil water balance was performed as follows:

$\Delta \theta=P+I-$ Eta

where $\Delta \theta$ is the soil water availability, $I$ is the irrigation depth calculated through the discharge monitored by the flow meter at the pumping station, then converted into water height units, and $P$ is the precipitation recorded in the climatic station at the field site.

\subsection{Evaluation of soil moisture content}

Soil water content $(\theta)$ was measured by Time Domain Reflectometry (TDR) in the IR and NR areas. Since the highest density of common bean roots concentrates at the top $20 \mathrm{~cm}$ soil layer (Bizari et al., 2010), and since the effect of water stress will show up early in this layer (Stone and Silveira, 1999), $\theta$ was monitored within the $0-20 \mathrm{~cm}$ profile. For each soil management, 14 plots of $5 \times 6 \mathrm{~m}$ were defined containing 11 seeding rows each. For each soil management, 14 TDR probes (one in each plot) were installed vertically into the soil and monitored once a day, at 8:00 am, during the 90 days of the crop cycle (see sketch on the bottom left hand side of Fig. 1).

The TDR probes were hand made and followed the methodology proposed by Souza et al. (2006). Each probe was composed of three rods ( $3.18 \mathrm{~mm}$ diameter and $20 \mathrm{~cm}$ long) and contained a coaxial cable RG 58. The inner end of the cable was welded to the central shaft and the outer sheath divided into two similar parts that were welded to the two outer rods. At the other end, a BNC connector was added, and finally, both ends with the welds were subsequently placed in high density silicone rubber mold which was filled with epoxy resin. Fig. 3 shows a view of the probe and a scheme of its dimensions.

The soil water content readings were logged into a TDR 100 , Campbell Scientific logger. Calibration of the TDR probes was accomplished in two PVC cylindrical columns, $25 \mathrm{~cm}$ long and $10 \mathrm{~cm}$ diameter, that were filled with soil from the research site previously sieved through a $2-\mathrm{mm}$ sieve. Starting with a saturated soil, the column was weighted, using a balance with $\pm 0.1 \mathrm{~g}$ accuracy, every day, to allow gradually decrease in water content during 18 days. At the same time, the soil apparent dielectric constant (Ka) was 


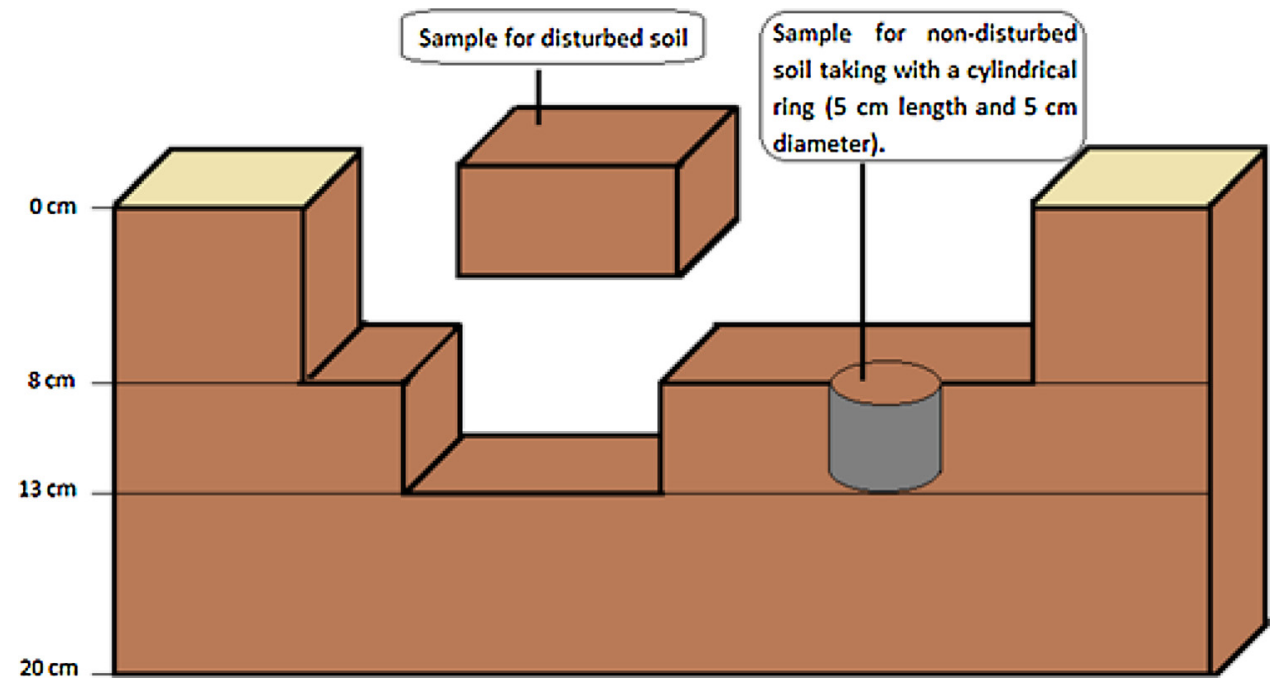

Fig. 2. Sketch showing the collection of soil samples for the soil water retention curve.

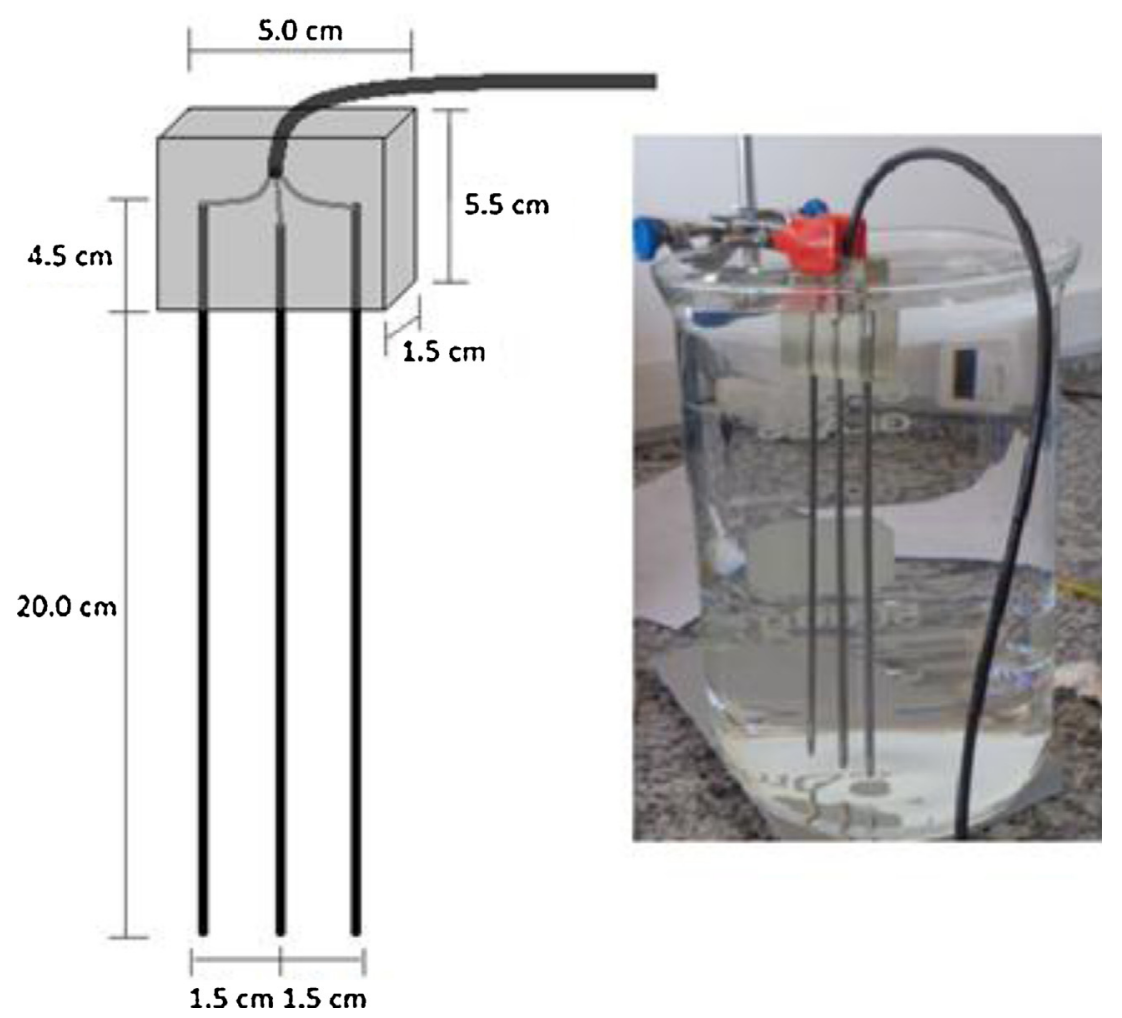

Fig. 3. Scheme and view of the time domain soil sensor probes.

determined with the TDR 100, Campbell Scientific logger. Likewise, the Topp equation (Topp et al., 1980) was also calculated as

$$
\begin{aligned}
& \theta\left(\frac{m^{3}}{m^{3}}\right)=4.3 \times 10^{-6} K a^{3}-5.5 \times 10^{-4} K a^{2}+2.92 \\
& \quad \times 10^{-2} \mathrm{Ka}-5.3 \times 10^{-2}
\end{aligned}
$$

where $\theta$ is the volumetric soil water content.

Topp equation is broadly used since $\theta$ can be determined from $\mathrm{Ka}$, independently of soil type, soil temperature, and soluble salt content.

The gravimetric moisture content was determined from the differences on soil column weights in two consecutive days; then, it was transformed into volumetric units considering the dry-density of the soil sample in the column. Finally, the ratio between the dried soil weight $\left(24 \mathrm{~h}\right.$ in the oven at $T=105^{\circ} \mathrm{C}$ ) and the column volume was calculated yielding $1.1 \mathrm{~g} \mathrm{~cm}^{-3}$.

\subsection{Evaluation of crop production}

The total number of pods, the average pod size, the average number of grains per pod, the number of grains per plant and the yield (expressed as h $^{-1}$ ) were evaluated 86 days after emergence (DAE). In each plot, ten consecutive plants were collected along its central line. The pod size was determined using a ruler 


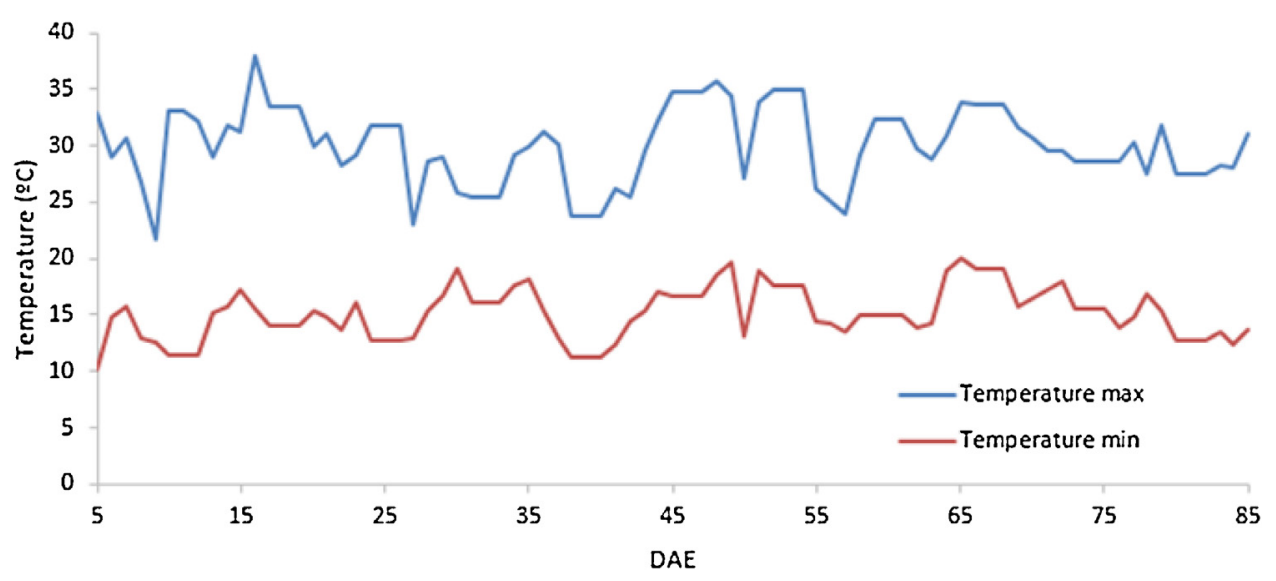

Fig. 4. Distribution of temperature during the common bean cycle in 2014. (DAE: days after emergency).

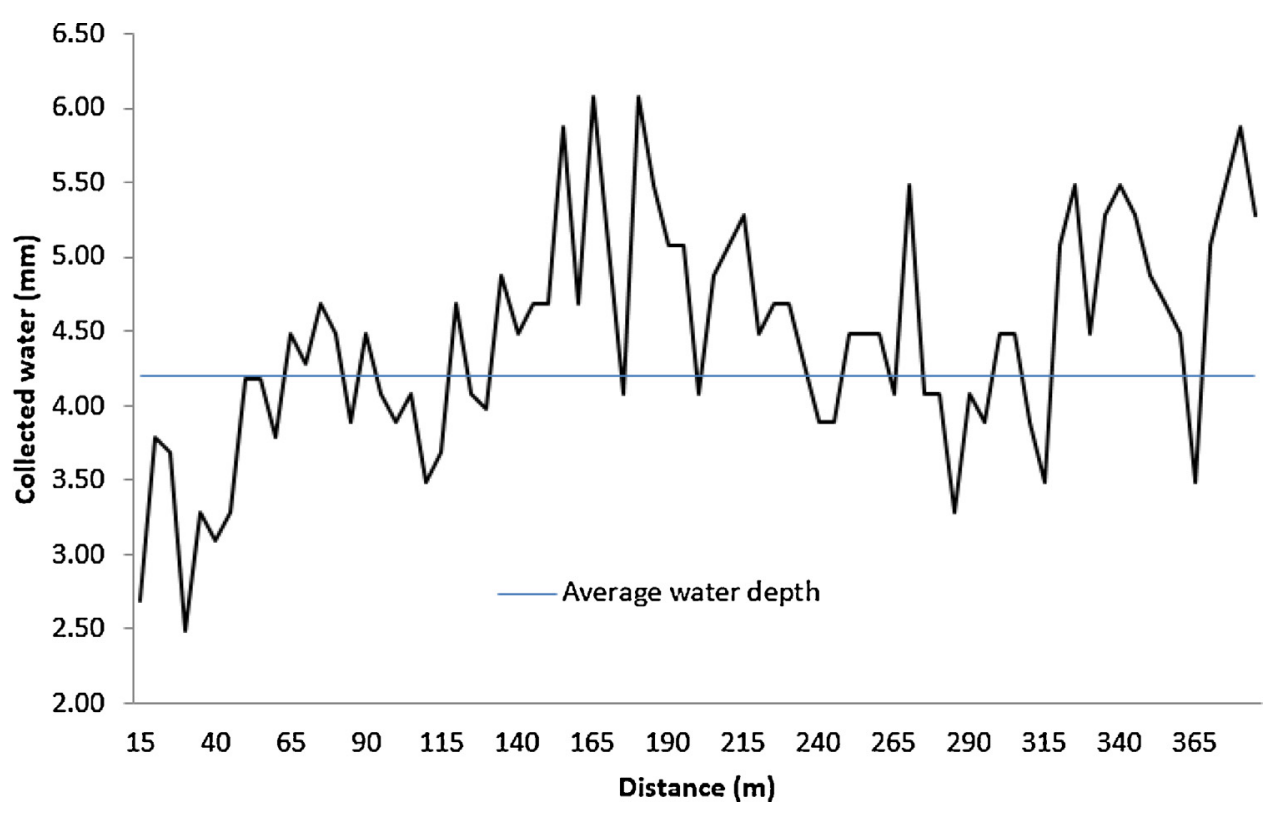

Fig. 5. Water distribution along the pivot center.

(minimum division $1 \mathrm{~mm}$ ) and a string. Likewise, yield was calculated weighing the grain at $13 \%$ moisture.

All measurements were statistically evaluated considering a completely randomized design with two treatments: soil management IR (incorporation of crop residues) and NR (no-incorporation of crop residues) and 14 repetitions of treatment in a total of 28 plots. Student's $t$-test was perfomed at 0.05 significance level.

\section{Results and discussion}

Air temperature in the experimental site varied from $9{ }^{\circ} \mathrm{C}$ to $38^{\circ} \mathrm{C}$, the average temperature was $22.6^{\circ} \mathrm{C}$ (Fig. 4). From 2010 to 2013 during the months coinciding with the cycle of common bean, the average rainfall recorded in the area was $400 \mathrm{~mm}$, and irrigation was applied to cover the crop water requirements at specific phenology stages. However, in the year 2014, it not only dropped to $249 \mathrm{~mm}$ but was unevenly distributed, coexisting concentrated rains with water scarcity periods. Thus, $146 \mathrm{~mm}$ of water was supplied by irrigations programmed in four-day intervals along the bean cycle.
The water distribution obtained in the field evaluation of the center pivot is shown in Fig. 5. The system applied an average water depth of $4.25 \mathrm{~mm}$ with Christiansen uniformity coefficient (CUC) equal to $85 \%$. This value is considered good (Ramos and Mantovani, 1994; ABNT, 1998; Tarjuelo, 2005) thus, it can be concluded that the farmer manages properly the irrigation system (pressure and time) and the variability of water application along the center pivot is within the advisable limits for maintaining good water uniformity.

\subsection{Soil water retention}

The comparison between soil water retention curves from the disturbed (IR) and non-disturbed (NR) soil samples are depicted in Fig. 6. It is observed that for a given soil water tension, the soil water content $\theta$ in the IR management is smaller than in the NR management and that for the same $\theta$, the first holds it with less tension. Likewise, the $\theta$ saturation in the IR is higher than NR but the macropores will empty sooner, and its minimum soil water content (near 24\%) will be smaller than NR (near 34\%). So, the water retention capacity of soils under NR management would be higher than IR. Since soil management techniques alter soil aggregates (Araújo 


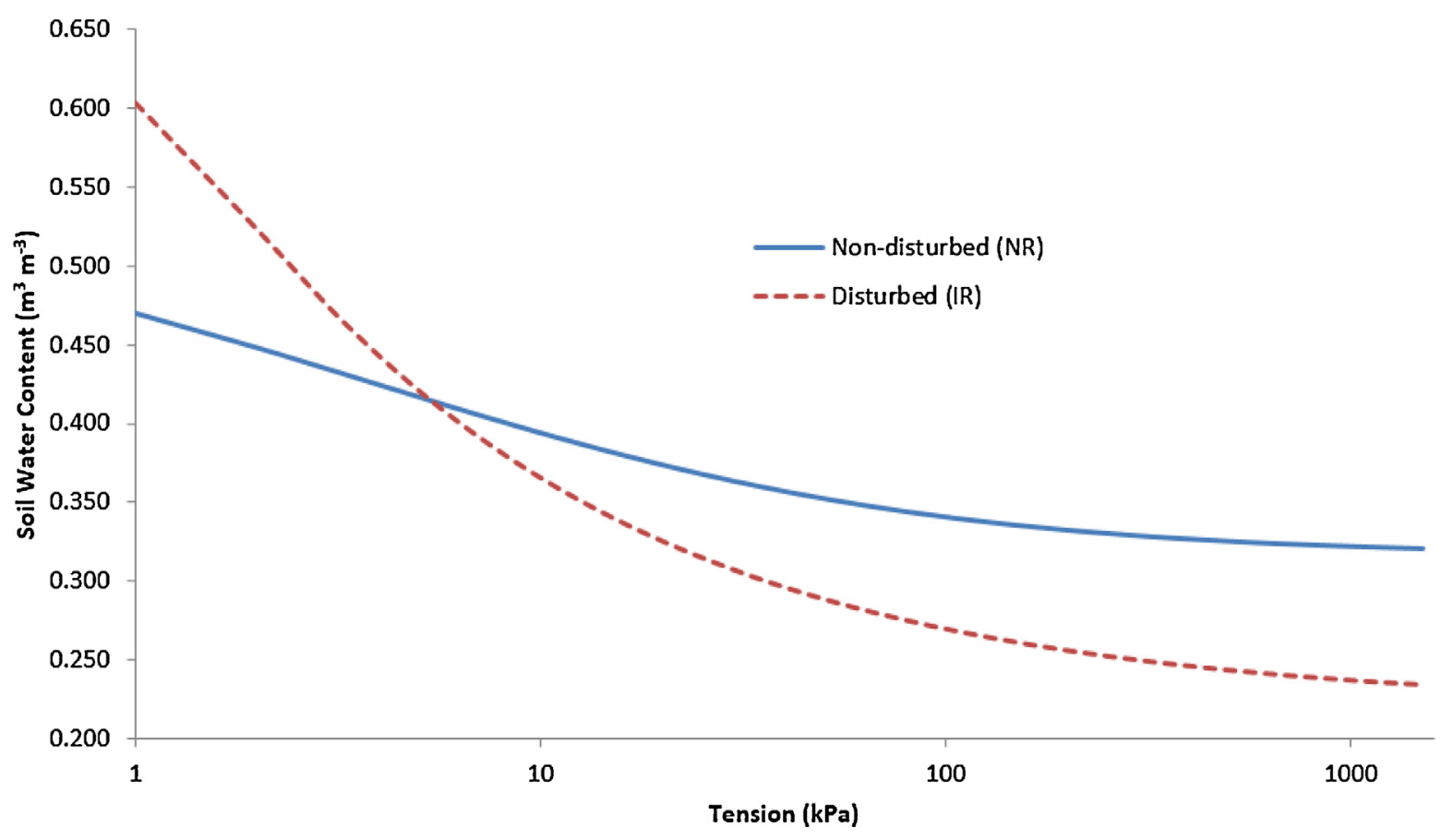

Fig. 6. Soil retention curves.

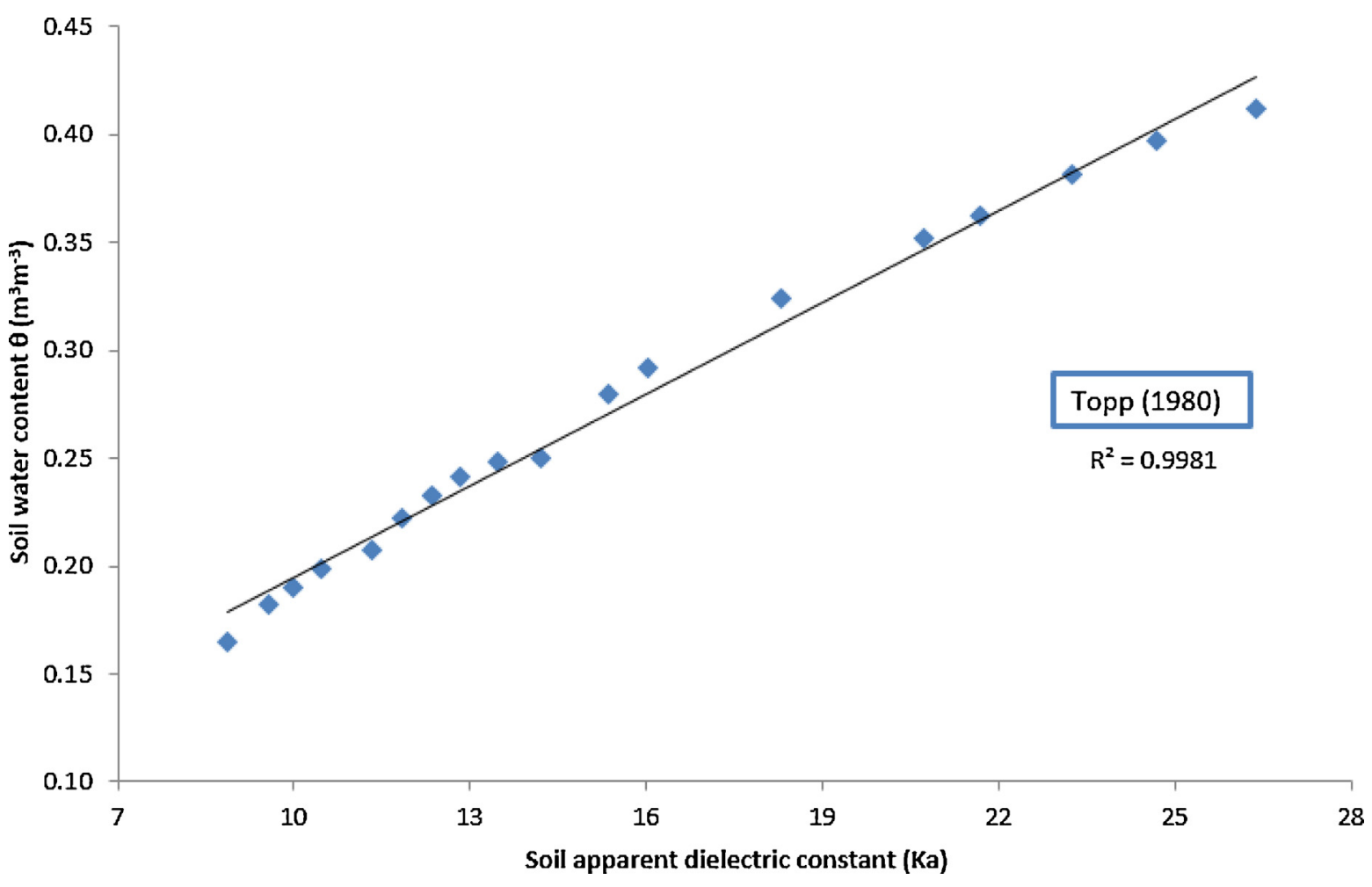

Fig. 7. Calibration curves of TDR probes.

et al., 2010), it would be expected that NR soils have developed a structure with a fine pore space network; however in IR soils, the time elapsed, after the incorporation of crop residues, approximately three months, would had been too short to settle down the aggregates and develop a proper structure. In addition, the reduction in water retention is caused, mainly, by the variation in the amount of pores responsible for the soil water availability reducing the permanent wilting point as well (Silva et al., 2014).
In summary, soil water content would be higher in NR soils than in IR, although water will be held with higher tension and the plant root system will require higher energy to absorb it.

\subsection{TDR probes calibration}

The average value of the two PVC columns in the TDR probe calibration is depicted in Fig. 7. It is observed that the 


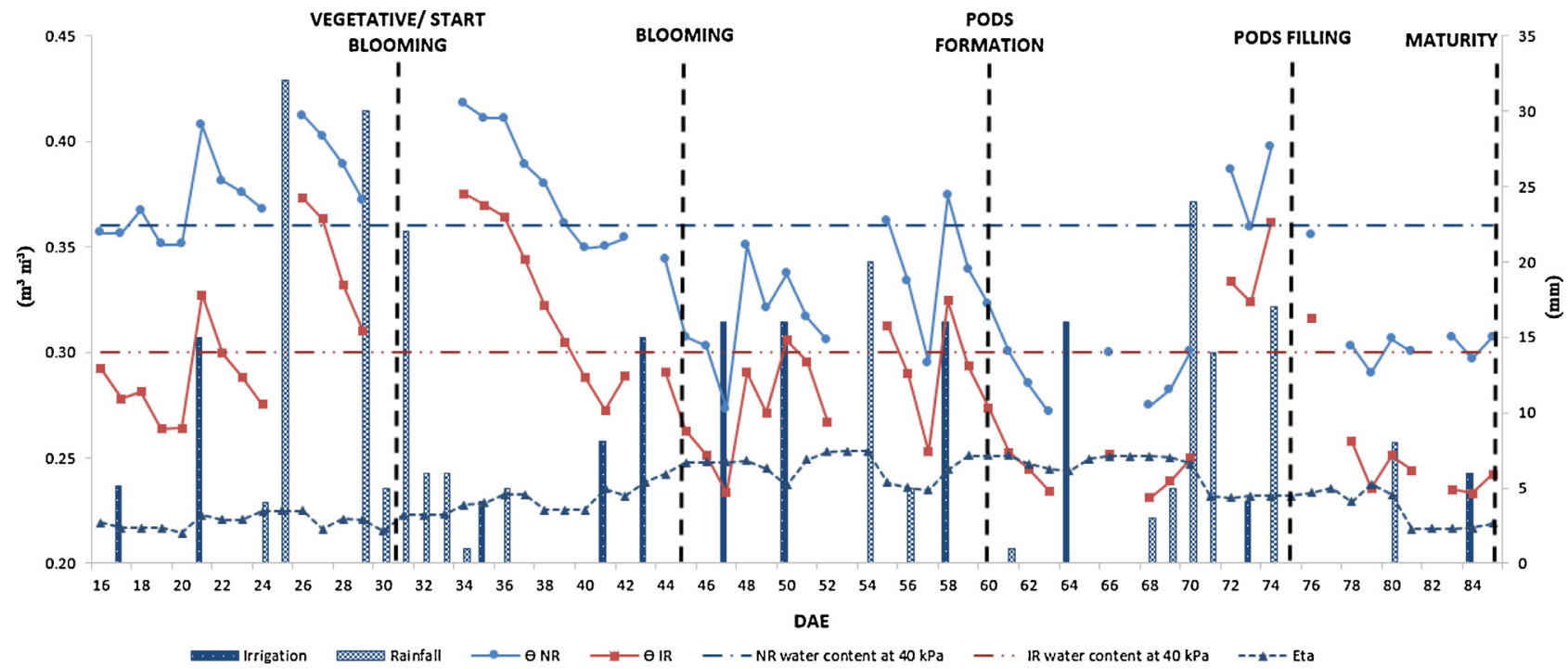

Fig. 8. Soil water content, rainfall and irrigation depths during common bean cycle.

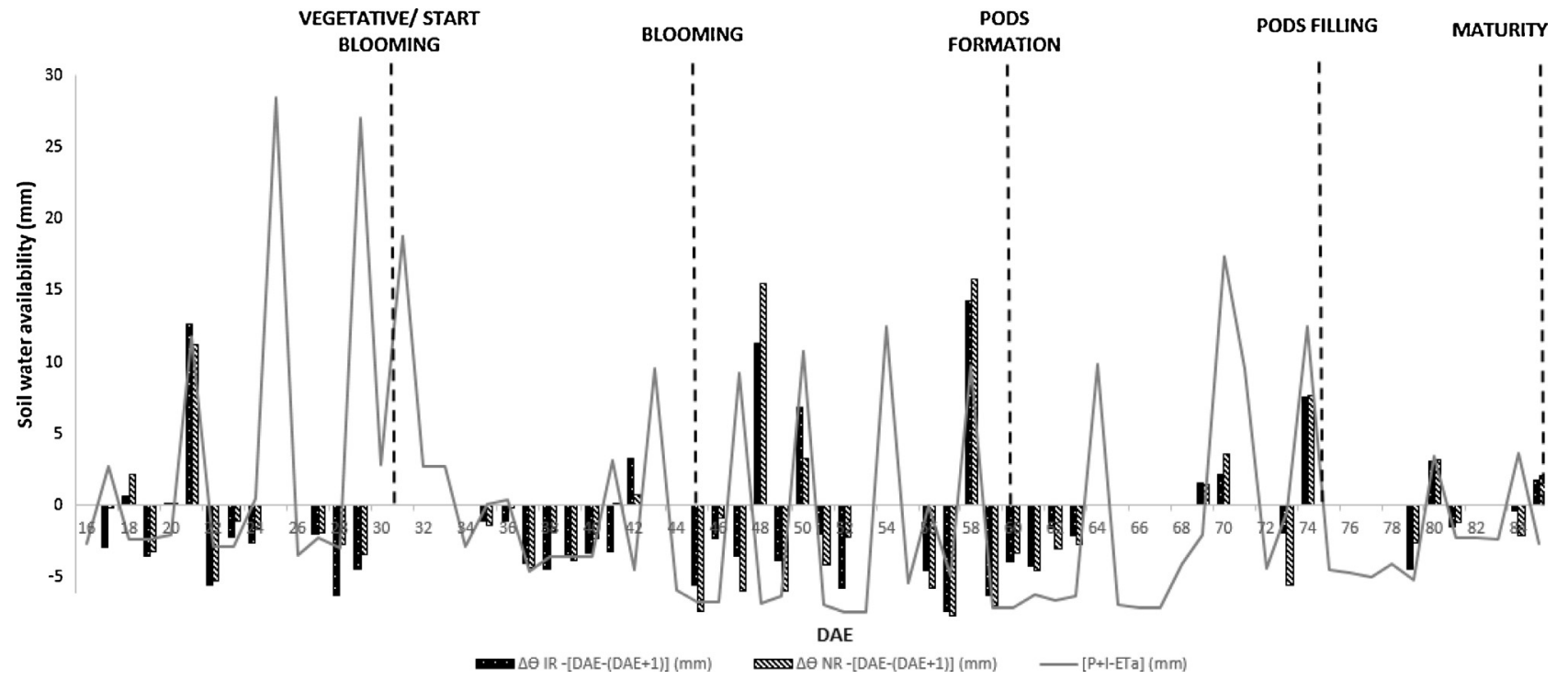

Fig. 9. Soil water variation measured in the field during common bean cycle and calculated by the balance Eq. (4).

experimental calibration curve agrees with Topp equation and, since this is valid and accurate for most of mineral soils (Tommaselli and Bacchi, 2001), it was used in the field for the measurement of $\theta$.

\subsection{Assessment of soil water content and soil water availability}

Fig. 8 shows the precipitation, irrigation and actual evapotranspiration depths and the average soil water content along the crop cycle of common beans. The $\theta$ was logged daily at 8:00 am except for certain dates which coincided with either the application of pesticides or heavy precipitation events that flooded the soil. The coefficient of variation among $\theta$ readings was 0.12 and $0.14{\mathrm{~m} 3 \mathrm{~m}^{-3}}^{-3}$ in NR and IR, respectively.

The rainfall shortage during the period of the study became an issue compromising the supply of water for irrigation. In consequence, the center pivot applied less than $16 \mathrm{~mm}$ in most irrigation events.

It is observed that even though the pattern of $\theta$ evolution was similar in both soil managements, the soil water content was higher (from 0.27 to $0.41 \mathrm{~m}^{3} \mathrm{~m}^{-3}$ ) in NR areas than in IR (from 0.23 to $0.37 \mathrm{~m}^{3} \mathrm{~m}^{-3}$ ) along the crop cycle and it decreases after 36 DAE. The $\theta$ drop was more drastic in the days with lack of rain. This scenario continued up to $54 \mathrm{DAE}$ coinciding with the phenology stage of grain filling which required a higher evapotranspiration and thus, higher soil water availability.

Rainfall and irrigation were almost absent from 59 to $67 \mathrm{DAE}$ (reproductive stage) and $\theta$ dropped steeply. Likewise, irrigation was reduced due to a treatment for the white mold (Sclerotinia sclerotiorum) infestation that affected the crop, as well as for saving water which was scarce. This type of infestation is common in center pivot irrigated areas and may cause $30-100 \%$ reduction in crop yield if farmers do not adopt preventive measures, mainly during the rainy season (Oliveira, 2005).

Soil water content increased during the rainy season (from 67 to 74 DAE) coinciding with the pod formation and early grain filling stages, and it progressively declined beyond $75 \mathrm{DAE}$ at the end of the crop cycle (grain maturity).

Fig. 8 also depicts a horizontal line which is the soil water content that would correspond to $40 \mathrm{kPa}$ tension (see Fig. 6). 
Table 2

Mean values for the crop variables evaluated 86 days after emergence DAE.

\begin{tabular}{|c|c|c|c|c|c|}
\hline & Pod size $(\mathrm{cm})$ & No. grains per plant & No. pods per plant & Yield ( ha $\left.^{-1}\right)$ & No. grains Per pod \\
\hline NR & $9.34 a$ & $4.73 a$ & $23.08 a$ & $4.95 a$ & 109.0a \\
\hline IR & $9.29 a$ & $4.72 \mathrm{a}$ & $22.99 a$ & $5.05 a$ & $108.7 \mathrm{a}$ \\
\hline
\end{tabular}

Note: values with the same letter show no-statistical significance in the Student's $t$-test at 0.05 level.

This is considered a threshold value to avoid water stress by the application of irrigation (Lopes et al., 2011; Sant'Ana et al., 2011; Silveira and Stone, 2001). It is noted that the plants suffer a similar period of water stress during all crop cycle in both IR and NR soils. The longest period started at the end of pod formation (58 DAE) and extended to the pod filling (70 DAE). The root system of common beans usually develops within the first $40 \mathrm{~cm}$ soil layer as it was observed by Bizari et al. (2010) in a clay latosol soil, although it could reach up to $1.5 \mathrm{~m}$ depth depending on soil conditions (Fujiwara et al., 1994). Likewise, the deeper soil layers generally contain higher soil moisture than the shallow ones, either in direct planting or in conventional soil management (Zanette et al., 2007). So, it is likely that in this study, the root system of common beans has withdrawn water from deeper soil layers to meet the crop water requirements in the water stress scenarios during the flowering to pod filling periods.

Fig. 9 depicts the soil water availability trend calculated as the difference between $\theta$ measured in the field, in two consecutive days, and by the balance Eq. (4). It is noted that the ETP was calculated considering the solar radiation measured in a weather station $20 \mathrm{~km}$ north of the experimental site, and that the crop coefficients corresponded to those of common beans grown in another area of São Paulo state. In addition, neither the soil spatial variability, inherent to the change in soil properties, nor the deep percolation beyond $20 \mathrm{~cm}$, was measured. Taking into account these remarks, it is observed that the trend in the estimation of soil water availability by both procedures matched properly. Precipitation and irrigation only covered the crop water requirements for most of the days within the vegetative stage. Also, the variation of soil water availability was higher in IR than in NR conditions at this stage. The canopy of the plant is small during the vegetative phase and soil evaporation will predominate over transpiration. Since crop residues left on the soil surface reduce evaporation, the IR conditions would have a higher decrease in soil water availability to meet the crop water requirement that would be similar in both soils.

\subsection{Crop production}

No significant differences were observed in the NR and IR soil managements regarding the variables studied for yield (see Table 2).

Since the difference in soil water availability during the crop cycle was small in both treatments, a similar yield would have been expected. Previous results on common beans have shown that, under stress, the plants have a reduced number of pods (Miorini et al., 2011), less pods per plant (Miorini et al., 2011; Stone et al., 1988), less grains per pod (Carvalho, 2013) and number of pods (Miorini et al., 2011). Also, the plant size was smaller independently of the event of water stress (Miorini et al., 2011).

\section{Conclusions}

For the same irrigation management along the common bean cycle, the incorporation of maize residues in the soil (IR) led to soil moisture contents lower than the maize residues over the soil surface (NR). However, both soil managements had similar soil water content and variation and they would have similar demand of water for irrigation.
For the same soil water content, NR soils hold it tightly in the pore space and the root plant system will require higher energy to absorb it. Thus, it is expected that the root system in IR soils management will be shallower than in NR since it will withdraw water easily within the first $20 \mathrm{~cm}$. However, the other will extend vertically searching for available water in deeper layers.

Considering the threshold of $40 \mathrm{kPa}$, the plants of common beans suffered water stress along the whole crop cycle and at the same physiologic stages in both IR and NR soils management. The longest period started at the end of pod formation (58 DAE) and extended to the pod filling (70 DAE).

The pod size, number of grains per plant, number of pods, yield and number of grains per pod in common bean plants were nonstatistical significant in the $T$ test at 0.05 significant level.

\section{Acknowledgments}

The authors gratefully acknowledge the financial support provided by CAPES and CNPq in Brazil. Likewise, they would like to thank the collaboration of Abel Rodrigues Simões Junior from "Olhos D'água" farm, the No-till and Planting in the Straw Irrigators of South western of São Paulo ASPIPP and the Technical University of Madrid.

\section{References}

ABNT, 1998. NBR 14244. Associação Brasileira de Normas Técnicas, Rio de Janeiro. Alfonsi, R.R., Pedro Jr., M.J., Arruda, F.B., Ortolani, A.A., Camargo, M.B.P., Brunini, O., 1990. Métodos Agrometeorológicos Para o Controle da Irrigação, 133rd ed. Instituto Agronômico de Campinas, Campinas.

Allen, R., Pereiras, L.S., Raes, D., Smith, M., 2006. Evapotranspiración del cultivo: Guías para la determinación de los requerimientos de agua de los cultivos. Estud. FAO Riego y Dren. 56, 298.

Alves, R., 2015. ANA e Embrapa concluem levantamento sobre irrigação com pivôs centrais no Brasil [WWW Document]. URL http://www2.ana.gov.br/Paginas/ imprensa/noticia.aspx?id_noticia=12669 (accessed 11.27.15.).

Araújo, F.S., Salviano, A.A.C., Leite, L.F.C., de Souza, Z.M., de Sousa, A.C.M., 2010 Physical quality of a yellow latossol under integrated crop-livestock system. Rev. Bras. Ciência do Solo 34, 717-723, http://dx.doi.org/10.1590/S010006832010000300013.

Benjamin, J.G., 1993. Tillage effects on near-surface soil hydraulic properties. Soil Tillage Res. 26, 277-288, http://dx.doi.org/10.1016/0167-1987(93)90001-6.

Bescansa, P., Imaz, M.J., Virto, I., Enrique, A., Hoogmoed, W.B., 2006. Soil water retention as affected by tillage and residue management in semiarid Spain. Soil Tillage Res. 87, 19-27, http://dx.doi.org/10.1016/j.still.2005.02.028.

Bhattacharyya, R., Pandey, S.C., Bisht, J.K., Bhatt, J.C., Gupta, H.S., Tuti, M.D., Mahanta, D., Mina, B.L., Singh, R.D., Chandra, S., Srivastva, A.K., Kundu, S., 2013 Tillage and irrigation effects on soil aggregation and carbon pools in the indian sub-himalayas. Agron. J. 105, 101-112, http://dx.doi.org/10.2134/agronj2012. 0223.

Bhattacharyya, R., Prakash, V., Kundu, S., Gupta, H.S., 2006. Effect of tillage and crop rotations on pore size distribution and soil hydraulic conductivity in sandy clay loam soil of the Indian Himalayas. Soil Tillage Res. 86, 129-140, http://dx.doi. org/10.1016/j.still.2005.02.018.

Bhattacharyya, R., Tuti, M.D., Kundu, S., Bisht, J.K., Bhatt, J.C., 2012. ConservatIon tillage impacts on soil aggregation and carbon pools in a Sandy Clay Loam Soil of the Indian Himalayas. Soil Sci. Soc. Am. J. 76, 617, http://dx.doi.org/10.2136/ sssaj2011.0320.

Bizari, D.R., Matsura, E.E., Chamlet, J., Mesquita, M., Salvador, C.A., 2010. Relationship between effective rooting depth and aerial part in the irrigated bean crop in no tillage system. Rev. Bras. Agric. Irrig.-RBAI 4, 172-183, http:// dx.doi.org/10.7127/RBAI.V4N300012.

Blanco-Canqui, H., Lal, R., 2007. Soil structure and organic carbon relationships following 10 years of wheat straw management in no-till. Soil Tillage Res. 95 240-254, http://dx.doi.org/10.1016/j.still.2007.01.004.

Boulal, H., Mateos, L., Gómez-Macpherson, H., 2011. Soil management and traffic effects on infiltration of irrigation water applied using sprinklers. Irrig. Sci. 29, 403-412, http://dx.doi.org/10.1007/s00271-010-0245-1. 
Bourgault, M., Smith, D.L., 2010. Comparative study of common bean (Phaseolus vulgaris L.) and mungbean (Vigna radiata (L.) Wilczek) response to seven watering regimes in a controlled environment. Crop Pasture Sci. 61, 918-928, http://dx.doi.org/10.1071/Cp10141.

Brouder, S.M., Gomez-Macpherson, H., 2014. The impact of conservation agriculture on smallholder agricultural yields: a scoping review of the evidence. Agric. Ecosyst. Environ. 187, 11-32, http://dx.doi.org/10.1016/j.agee. 2013.08.010.

Broughton, W.J., Hernández, G., Blair, M., Beebe, S., Gepts, P., Vanderleyden, J., 2003. Beans (Phaseolus spp.)-model food legumes. Plant Soil 252, 55-128, http://dx.doi.org/10.1023/A:1024146710611.

Buschiazzo, D.E., Panigatti, J.L., Unger, P.W., 1998. Tillage effects on soil properties and crop production in the subhumid and semiarid Argentinean Pampas. Soil Tillage Res. 49, 105-116, http://dx.doi.org/10.1016/S0167-1987(98)00160-3.

Carlesso, R., Jadoski, S.O., Maggi, M.F., Petry, M., 2007. Efeito da lâmina de Irrigação na Senescência foliar do feijoeiro. Irriga 12, 545-556

Carvalho, J.J., 2013. Resposta do feijoeiro comum à irrigação com défict, sob semedura direta. Universidade Estadual Paulista Julio de Mesquita Filho (Campus de Botucatu) Faculdade de Ciências Agronômicas.

Casão Junior, R., Araújo, A.G., Llanillo, R.F., 2012. No-till agriculture in southern Brazil: Factors that facilitated the evoluti on of the system and the development of the mechanizati on of conservati on farming.

Claessen, M.E.C., Barreto, W.D.O., Paula, J.L., de Duarte, M.N., 1997. Manual de Métodos de Análise de Solo. Embrapa.

Datiri, B.C., Lowery, B., 1991. Effects of conservation tillage on hydraulic properties of a Griswold silt loam soil. Soil Tillage Res. 21, 257-271, http://dx.doi.org/10. 1016/0167-1987(91)90024-R.

Didonet, A.D., 2005. Ecofisiologia e rendimento potencial do feijoeiro. In: Del Peloso, M.J., Melo, L.C. (Eds.), Potencial de Rendimento Da Cultura Do Feijoeiro Comum. Embrapa Arroz e Feijão, Santo Antonio de Goiás, pp. 9-37.

Dourado-Neto, D., Nielsen, D.R., Hopmans, J.W., Reichardt, K., Bacchi, O.O.S., Lopes, P.P., 2000. Software to model soil water retention curves (SWRC, version 2.00). Sci. Agric. 57, 191-192.

Fancelli, A.L., Dourado Neto, D., 1991. Feijão Irrigado, 2nd ed. ESALQ/USP, Piracicaba.

FAO, 2009. Food Productions [WWW Document]. URL http://faostat.fao.org/site/ 291/default.aspx (accessed 5.5.15.).

Fujiwara, M., Kurachi, S.A.H., Arruda, F.B., Pires, R.C.M., Sakai, E., 1994. A Técnica de estudo de raízes pelo método do trado. Bol. Técnico do IAC 153.

Govaerts, B., Fuentes Mezzalama, M., Mezzalama, M., Nicol, J.M., Deckers, J., Etchevers, J.D., Figueroa-Sandoval, B., Sayre, K.D., 2007. Infiltration, soil moisture, root rot and nematode populations after 12 years of different tillage, residue and crop rotation managements. Soil Tillage Res. 94, 209-219, http:// dx.doi.org/10.1016/j.still.2006.07.013.

Gruber, S., Möhring, J., Claupein, W., 2011. On the way towards conservation tillage-soil moisture and mineral nitrogen in a long-term field experiment in Germany. Soil Tillage Res. 115-116, 80-87, http://dx.doi.org/10.1016/j.still. 2011.07.001.

Guimarães, C.M., 1996. Relações hidricas. In: Araújo, R.S., Rava, C.A., Stone, L.F (Eds.), Cultura Do Feijoeiro Comum No Brasil. Potafos, Piracicaba, p. 786

Guimarães, C.M., Stone, L.F., Del Peloso, M.J., de Oliveira, J.P., 2011. Genãtipos de feijoeiro comum sob deficióncia hêdrica. Rev. Bras. Eng. Agrícola e Ambient 15, 649-656, http://dx.doi.org/10.1590/S1415-43662011000700001.

Hargreaves, G.H., Samani, Z.A., 1985. Reference Crop Evapotranspiration from Temperature. American Society of Agricultural Engineers, pp. 96-99, http://dx. doi.org/10.13031/2013.26773.

Jemai, I., Ben Aissa, N., Ben Guirat, S., Ben-Hammouda, M., Gallali, T., 2013. Impact of three and seven years of no-tillage on the soil water storage, in the plant root zone, under a dry subhumid Tunisian climate. Soil Tillage Res. 126, 26-33, http://dx.doi.org/10.1016/j.still.2012.07.008.

Keller, T., Arvidsson, J., Dexter, A., 2007. Soil structures produced by tillage as affected by soil water content and the physical quality of soil. Soil Tillage Res. 92, 45-52, http://dx.doi.org/10.1016/j.still.2006.01.001.

Ladha, J.K., Kumar, V., Alam, M.M., Sharma, S., Gathala, M.K., Chandna, P., Saharawat, Y.S., Balasubramanian, V., 2009. Integrating crop and resource management technologies for enhanced productivity, profitability and sustainability of the rice-wheat system in South Asia. In: Ladha, J.K. (Ed.) Integrated Crop and Resource Management in the Rice-Wheat System of South Asia. IRRI, Los Baños, pp. 69-108.

Lipiec, J., Kuś, J., Słowińska-Jurkiewicz, A., Nosalewicz, A., 2006. Soil porosity and water infiltration as influenced by tillage methods. Soil Tillage Res. 89, 210-220, http://dx.doi.org/10.1016/j.still.2005.07.012.

Lopes, A.S., Oliveira, G.Q., Filho, S.N.S., Goes, R.J., Camacho, M.A., 2011. Manejo de irrigação e nitrogênio no feijoeiro comum cultivado em sistema plantio direto. Rev. Ciência Agronômica 42, 51-56, http://dx.doi.org/10.1590/S180666902011000100007.
Miorini, T.J.J., Saad, J.C.C., Menegale, M.L., 2011. Supressão de água em diferentes fases fenológicas do feijoeiro (Phaseolus vulgaris L.). Irriga 16, 360-368.

Monteiro, P.F.C., Filho, R.A., Monteiro, R.O.C., 2010. Efeitos da irrigação e da adubação nitrogenada sobre as variaveis agronômicas da cultura do feijão. Irriga 15, 386-400.

Mulumba, L.N., Lal, R., 2008. Mulching effects on selected soil physical properties. Soil Tillage Res. 98, 106-111, http://dx.doi.org/10.1016/j.still.2007.10.011.

Nielsen, D.C., Vigil, M.F., Benjamin, J.G., 2009. The variable response of dryland corn yield to soil water content at planting. Agric. Water Manag. 96, 330-336, http://dx.doi.org/10.1016/j.agwat.2008.08.011.

Oliveira, F., 2005. Manejo do mofo branco. Rev. DBO Agrotecnol., 8-13.

Palm, C., Blanco-Canqui, H., DeClerck, F., Gatere, L., Grace, P., 2014. Conservation agriculture and ecosystem services: an overview. Agric. Ecosyst. Environ. 187, 87-105, http://dx.doi.org/10.1016/j.agee.2013.10.010.

Raij, B.V., Andrade, J.C., Cantarella, H., Quaaggio, J.A., 2001. Análise Química para Avaliação da Fertilidade de Solos Tropicais. IAC, Campinas.

Ramos, M.M., Mantovani, E.C., 1994. Sistemas de irrigação e seus componentes. In: Costa, E.F., Vieira, R.F., Viana, P. (Eds.), Quimigação: Aplicação de Produtos Químicos E Biológicos via Irrigação. EMBRAPA-CNPMS-SPI, Brasília, pp. 41-84.

Raziei, T., Pereira, L.S., 2013. Estimation of ETo with Hargreaves-Samani and FAO-PM temperature methods for a wide range of climates in Iran. Agric. Water Manag. 121, 1-18, http://dx.doi.org/10.1016/j.agwat.2012.12.019.

Sant'Ana, E.V.P., Santos, A.B., da Dos Silveira, P.M., 2011. Eficiência de uso de nitrogênio em cobertura pelo feijoeiro irrigado. Rev. Bras. Eng. Agrícola e Ambient, 458-462, http://dx.doi.org/10.1590/S1415-43662011000500004.

Sharma, P., Abrol, V., Sharma, R.K., 2011. Impact of tillage and mulch management on economics, energy requirement and crop performance in maize-wheat rotation in rainfed subhumid inceptisols, India. Eur. J. Agron. 34, 46-51, http:// dx.doi.org/10.1016/j.eja.2010.10.003.

Silva, B., Silva, E. da, Oliveira, G. de, 2014. Plant-available soil water capacity: estimation methods and implications. Rev. Bras. Ciência do Solo 38, 464-475, http://dx.doi.org/10.1590/S0100-06832014000200011.

Silveira, P.M. da, Silva, O.F. da, Stone, L.F., Silva, J.G. da, 2001. Efeitos do preparo do solo, plantio direto e de rotações de culturas sobre o rendimento e a economicidade do feijoeiro irrigado. Pesqui. Agropecu. Bras. 36, 257-263, http://dx.doi.org/10.1590/S0100-204X2001000200007.

Silveira, P.M., Stone, L.F., 2001. Irrigação do Feijoeiro. Embrapa Arroz e Feijão, Santo Antônio de Goiás.

Singh, S.P., 1995. Selection for water-stress tolerance in interracial populations of common bean. Crop Sci. 35, 118-124.

Sorrenson, W.J., Montoya, L.J., 1984. Economic Implications of Soil Erosion and Soil Conservation Practices in Paraná, Brazil. Deutsche Gesellschaft für Technische Zusammenarbeit, Eschborn.

Souza, C.F., Matsura, E.E., Folegatti, M.V., Coelho, E.F., Or, D., 2006. Sondas de TDR para a estimativa da umidade e da condutividade elétrica do solo. Irriga 11, $12-25$.

Stone, L.F., Moreira, J.A.A., Silva, S.C. da, 1988. Efeitos da tensão da água do solo sobre a produtividade e crescimento do feijoeiro 1 (23), 161-167.

Stone, L.F., Silveira, P.M. da, 1999. Efeitos do sistema de preparo na compactação do solo, disponibilidade hídrica e comportamento do feijoeiro. Pesqui. Agropecu. Bras. 34, 83-91, http://dx.doi.org/10.1590/S0100-204X1999000100012.

Tarjuelo, J.M., 2005. El riego por aspersion y su tecnología, $3^{\text {a }}$ ed. Mundi-Prensa.

Thomas, G.A., Dalal, R.C., Standley, J., 2007. No-till effects on organic matter, pH, cation exchange capacity and nutrient distribution in a Luvisol in the semi-arid subtropics. Soil Tillage Res. 94, 295-304, http://dx.doi.org/10.1016/j.still.2006. 08.005 .

Tommaselli, J.T.G., Bacchi, O.O.S., 2001. Calibração de um equipamento de TDR para medida de umidade de solos. Pesqui. Agropecu. Bras. 36, 1145-1154, http://dx.doi.org/10.1590/S0100-204X2001000900008.

Topp, G.C., Davis, J.L., Annan, A., 1980. Electromagnetic determination of soil water content: measurement in coaxial transmission lines. Water Resour. Res. 16, 576-583.

Verhulst, N., Govaerts, B., Verachtert, E., Castellanos-Navarrete, A., Mezzalama, M. Wall, P., Chocobar, A., Deckers, J., Sayre, K.D., 2010. Conservation agriculture. Improving soil quality for sustainable production systems? In: Lal, R., Stewart, B.A. (Eds.), Advances in Soil Science: Food Security and Soil Quality. CRC Press, Boca Raton, pp. 137-208.

Zanette, S.V., Sampaio, S.C., Silvestre, M.G., Boas, M.A.V., Uribe-Opazo, M.A., Queiroz, M.M.F. de, 2007. Análise espacial da umidade do solo cultivado com soja sob dois sistemas de manejo. Rev. Bras. Eng. Agrícola e Ambient. 11, 239-247, http://dx.doi.org/10.1590/S1415-43662007000300001. 